\title{
nature
}

\section{When steady state is no longer good enough}

The US Department of Energy will have to build something soon if it is to retain its role as provider of state-of-theart scientific facilities. It should draw up a realistic medium-term plan for facility construction.

T he dog's breakfast that makes up US science policy does have a certain rationale. The National Institutes of Health (NIH) and the National Science Foundation (NSF) provide grants to university scientists. The Pentagon supports computer science and engineering. The National Aeronautics and Space Administration holds televised press conferences. And the Department of Energy provides premium facilities, that no university - or even group of universities - could ever afford, to keep US science at the cutting edge.

Although these machines used to be primarily for physicists, their reach is increasingly broad. Neutron and splendid new light sources are useful for research in all kinds of materials science, and also make possible the study of organic molecules. Neutrons are especially powerful in this regard, as they interact well with light atomic nuclei.

The energy department has recently been confronted by opponents who would like to shut it down. Forced on to the defensive, it has balked at the cost of new machines. Although a stream of these are now coming on line, all were planned by the Bush administration. The Clinton administration stopped design work on a \$3-billion Advanced Neutron Source, the last and second most expensive of the facilities planned by Bush.

It is good that the department has succeeded in keeping the wolves from the door, and managed to defend its \$2-billion annual budget for civilian science. It has even consolidated that budget, with the administration acknowledging that it should be treated as well as NSF and NIH. But the Department of Energy's facilities are expensive to run, as well as to build, and unless they remain state-of-art, these operating costs will become impossible to justify.

In striking a balance between construction, operations and actual science, the department has rightly taken steps to ensure that existing facilities are well used. Ernie Moniz, a physicist from the Massachusetts Institute of Technology then at the White House, helped to implement a Scientific Facilities Initiative which provided badly needed resources for operations. In a fiscally restrictive climate, the need to make better use of existing facilities was something on which the administration and the Congress could agree.

Now Moniz is returning to Washington, as under-secretary at the energy department (see page 510). The fiscal climate has improved somewhat, although not to the point where new construction programmes will be embraced without reservation.

But when countries such as Taiwan, Australia and Canada are planning neutron sources better than anything extant in the United States, it is time for the US Department of Energy to think about the long term. The neutron situation is particularly acute (see page 503), and should at least be addressed by funding for a new National Spallation Neutron Source in next year's budget proposal.

Beyond that, the department needs to get over the trauma that it has been through during the past few years, and lay out a realistic multi-year programme for the new facilities at its non-defence laboratories that will justify their existence into the next century.

\section{Double trouble}

\section{Unesco should think again before endorsing an outright condemnation of human cloning.}

7 here has at times been something 'Kafkaesque' about the recent political debate on the ethics of human cloning. Politicians have been only too ready to make populist condemnations of a practice that still remains many years from realization. Others have found it convenient to leap on this moral bandwagon as a vehicle for delivering coded messages about an essentially separate issue, namely the morality of human abortion.

The latest victim of what appears at times to be virtually a witchhunt has been the laudable efforts of the United Nations Educational, Scientific and Cultural Organization (Unesco) to draft a universal 'declaration on the human genome' (see page 508). Four years of debate have produced a thoughtful set of guidelines on protecting human rights in the genetic age. Last week, the draft text was modified - apparently under political pressure from some member states - explicitly to identify "reproductive cloning of human beings" as a practice "contrary to human dignity".

Much of the motivation behind this move is unexceptionable. If human cloning did become widely practised, it would undermine our thinking about the moral status of individuals, in particular our confidence in our 'uniqueness'. To challenge that uniqueness would have profound implications, especially if it was done for commercial or political reasons. But is this sufficient reason to seek a blanket condemnation of the techniques themselves? Some would argue yes, on the grounds that anything less implies approval, opening a loophole that would soon grow much bigger.

There are several problems with this argument. One is that it allows no exceptions - including practices that could well meet Unesco's criterion of maintaining human dignity; an example is the possibility that it could enable a man with total germ-cell failure nevertheless to become a biological father.

A second objection is that outright condemnation, without a clear and unambiguous moral justification, may make good religion, but never makes good politics. Attempting to impose moral standards from above that lack the legitimacy of acceptance from below is always dangerous and misguided.

Those ultimately responsible for the final text should think again. After all, the guidelines will not themselves be legally binding, and the more rigidly they are written, the greater the likelihood that they may be ignored. To reject a blanket condemnation of human cloning, while insisting on a clear set of moral principles by which techniques such as cloning should be judged by individual countries and communities, would be an act of political courage, not cowardice. 